\title{
DAMPAK SERVANT LEADERSHIP TERHADAP PEMBELAJARAN ORGANISASI DAN KINERJA GURU: STUDI PADA GURU-GURU SMA DAN SMK SE-KOTA MADIUN
}

\author{
Veronika Agustini Srimulyani (sveronikaagustinis@yahoo.co.id) \\ Kesia Tripena Hutajulu \\ Unika Widya Mandala Madiun
}

\begin{abstract}
This study aims to examine and analyze the influence of servant leadership to organizational learning and teacher performance, and analyze whether the effect of organizational learning mediate the relationship of servant leadership to teacher performance. The respondent in this study were high school teachers in Madiun, which amounts to 281 people. Research instrument used in testing the validity and reliability. The analysis tool used is simple regression, multiple regression, hypothesis testing device using $\mathrm{t}$ test and mediation. Questionnaire as a means of collecting primary data, Likert scale of measurement used by five (5) of alternative answers. Secondary data obtained from institutional documentation. Test results showed that the instrument is valid and reliable research, simple regression produced a positive un-standardized beta for all variables. Hypothesis states that the hypothesis was accepted. The results showed that: (1) servant leadership have positive and significant effect on organizational learning (2) servant leadership have positive and significant effect on teacher performance (3) organizational learning has positive and significant effect on teacher performance (4) Servant leadership had indirect impact on teacher performance with organizational learning as mediating variable.
\end{abstract}

Key Word: Servant Leadership, Organizational Learning, Teacher Performance

\section{PENDAHULUAN}

Pengelolaan pendidikan atau manajemen sekolah tidak dapat dipisahkan dari model kepemimpinan yang diadopsi kepala sekolah dalam menjalankan perannya sebagai seorang "leader". Hal ini disebabkan oleh adanya keterikatan yang kuat antara model kepemimpinan (leadership model) yang dipakai oleh kepala sekolah dengan keefektifan secara keseluruhan dari proses pendidikan di sekolah (Glatthorn, 2000). Pendapat ini pada dasarnya berakar pada konsep kepemimpinan pendidikan yang bermuara pada pembentukan dan pengembangan secara menyeluruh potensi manusia (warga sekolah) melalui penggunaan yang efektif akan sumber daya organisasi dan pengetahuan dan ketrampilan kepemimpinan (Weller, 2000). Disamping itu, kekomplekan tantangan-tantangan yang dihadapi oleh sekolah pada saat sekarang ini seiring semakin kompleksnyamasyarakat mengharuskan keberadaan suatu model kepemimpinan yang dapatmembantu sekolah dalam mengembangkan batas-batas dan fungsifungsitradisionalnya (Green, 2001). 
Kepemimpinan organisasi sampai saat ini tetap dianggap sebagai faktor yang sangat penting dalam mencapai efektivitas organisasi, demikian halnya dengan organisasi pendidikan. Penelitian tentang kepemimpinan terus berkembang, dan perkembangan terakhir tentang penelitian di bidang praktek kepemimpinan adalah kepemimpinan pelayan (Servant Leadership $=S L$ ).Penerapan aplikasi SL meliputi dunia bisnis, pendidikan, dan berbagai yayasan (Greenleaf 1970). Northouse (2001) mengungkapkan bahwa SL kurang dipublikasikan dan diteliti secara empiris. Oleh karena itu penelitian empiris tentang konsep SL perlu dikembangkan. Era kepemimpinan pelayan atau SL saat ini sedang menunjukkan tren meningkat dibandingkan dengan gaya kepemimpinan lainnya. Hal ini didorong oleh globalisasi yang semakin meluas dan membuat para pemimpin, dalam hal ini kepala sekolah dan wakil kepala sekolah, perlu merubah gaya kepemimpinannya. Bentuk kepemimpinan alternatif yang dapat diterapkan di institusi pendidikan adalah servant leadership, dimana ciri menonjol kepemimpinan pelayan ini adalah kepemimpinan yang berorientasi pada manusia.

Tulisan dan penelitian tentang apa yang dimaksudkan dengan servant leadership serta karakteristik servant leadership telah banyak ditulis dan diteliti. Beberapa peneliti pun sudah mulai mengembangkan instrumen pengukuran servant leadership. Namun penelitian dan pengukuran servant leadership di Indonesia, terlebih dalam setting institusi pendidikan tingkat menengah, masih sangat jarang. Pada saat ini, sebagian besar dunia pendidikan di Indonesia sedang dalam masa perubahan organisasi. Disamping itu penelitian empiris tentang servant leadership khususnya kepada kepala sekolah menengah atas belum dilakukan secara optimal. Pengujian untuk meningkatkan kepemimpinan yang baik secara empiris sebagai dasar pembinaan kepala sekolah juga masih belum banyak dilakukan. Di lain pihak, tantangan kepemimpinan dalam sekolah dewasa ini adalah memberdayakan semua potensi dan menjadikan sekolah sebagai komunitas pembelajar menuju perubahan-perubahan yang lebih bermakna. Kepemimpinan yang dibutuhkan dalam konteks ini adalah servant leadership.

Penelitian sebelumnya (Akhtar et al., 2012) yang berjudul: Impact of Transformational and Servant Leadership on Organizational Performance: A Comparative Analysis menyimpulkan bahwa kepemimpinan transformasional dan kepemimpinan servant memiliki dampak positif signifikan terhadap pembelajaran organisasi, dan pembelajaran organisasi berdampak pada peningkatan kinerja organisasi. Berdasarkan penelitian Marlikan (2011) pembelajaran organisasi berpengaruh positif dan signifikan terhadap kinerja karyawan.

Penelitian tentang kepemimpinan, saat ini sangat penting dilakukan dalam rangka mencari alternatif bentuk kepemimpinan di sekolah. Dalam rangka pelaksanaan manajemen berbasis sekolah, kepemimpinan di tingkat sekolah, merupakan posisi yang strategis dalam suatu organisasi sekolah. Salah model yang dieksplorasi dalam penelitian ini adalah servant leadership. Ada beberapa perbedaan dalam penelitian ini dengan penelitian terdahulu; 1) indikator pengukuran servant leadership mengacu pada Spears; 2) indikator kinerja guru menggunakan indikator khusus untuk pengukuran kinerja guru. Tujuan dari penelitian ini adalah untuk menganalisis pengaruh servant leadership terhadap pembelajaran organisasi serta menguji pengaruh langsung dan tidak langsung servant leadership terhadap kinerja guru dengan pembelajaran organisasi sebegai pemediasi dengan mengambil studi empiris pada guru-guru tetap di SMA dan SMK Negeri dan Swasta di Kota Madiun. 


\section{LANDASAN TEORI DAN PENGEMBANGAN HIPOTESIS}

\section{Servant Leadership}

Pendidikan merupakan suatu proses dan sistem terbuka yang berperan dalam pembentukan pribadi manusia. Salah satu unsur yang menentukan dalam proses pendidikan khususnya dalam lingkup sekolah, adalah kepemimpinan. Pengelolaan pendidikan atau manajemen sekolah tidak dapat dipisahkan dari model kepemimpinan yang diadopsi kepala sekolah dalam menjalankan perannya sebagai seorang "leader". Hal ini disebabkan oleh adanya keterikatan yang kuat antara model kepemimpinan (leadership model) yang dipakai oleh kepala sekolah dengan keefektifan secara keseluruhan dari proses pendidikan disekolah (Glatthorn 2000). Brahmasari (2008:132) mengemukakan bahwa semakin baik kepemimpinan yang digunakan pemimpin akan semakin baik pula kinerja karyawan. Kepemimpinan yang diperankan dengan baik oleh seorang pemimpin mampu memotivasi karyawan untuk bekerja lebih baik, hal ini akan membuat karyawan lebih hati-hati berusaha mencapai target yang diharapkan organisasi dan berdampak pada kinerja karyawan.

Robert K. Greenleaf, pencetus gerakan modern kepemimpinan pada tahun 1970 dalam esainya menciptakan istilah "pemimpin adalah seorang pelayan". Robert K. Greenleaf memperkenalkan konsep Servant Leadership yang menekankan peran seorang pemimpin sebagai "steward" (pelayan). Konsep servant leaderhip adalah kepemimpinan yang mendorong seseorang untuk melayani orang lain, sementara itu tetap fokus pada upaya untuk mencapai apa yang menjadi tujuan utama (visi dan misi) dari organisasi itu sendiri. Menurut Neuschel (dalam Aorora 2009:9), pemimpin pelayan adalah orang dengan rasa kemanusiaan yang tinggi. Blanchard (dalam Aorora 2009:12) menyatakan tentang tiga aspek kepemimpinan servant, yaitu: hati yang melayani (karakter kepemimpinan), kepala yang melayani (metoda kepemimpinan), dan tangan yang melayani (perilaku kepemimpinan). Spears (2005) menjelaskan 10 karakteristik penting seorang servant leader, yakni listening, empathy (menerima orang lain dan empati), foresight (kemampuan meramalkan), awareness (kesadaran diri), persuasion (membangun kekuatan persuasive), conceptualization (konseptualisasi), healing (kemampuan menyembuhkan), stewardship (kemampuan melayani), commitment to the growth of people (memiliki komitmen pada pertumbuhan manusia), dan community building (membangun komunitas).

\section{Pembelajaran Organisasi}

Pembelajaran organisasi merupakan salah satu sumber penting keuntungan kompetitif yang berkesinambungan yang dimiliki oleh perusahaan (de Geus 1988 dalam Hugo et al. 2009), dan menjadi pengendali penting kinerja perusahaan (Stata 1989 dalam Hugo et al. 2009). Pada lingkungan yang bergejolak tempat organisasi beroperasi, pembelajaran berkesinambungan menjadi pengendali kunci kemampuan perusahaan untuk tetap adaptif dan fleksibel, artinya untuk tetap bertahan dan bersaing secara efektif (Burke dkk. 2006 dalam Hugo et al. 2009).

Pembelajaran organisasi didasarkan pada prinsip-prinsip dasar pembelajaran yakni menerima dan mengumpulkan informasi, menginterpretasikannya, dan bertindak berdasarkan 
interpretasi dari informasi tersebut (Garvin 2000). Pembelajaran organisasi menyediakan prinsip-prinsip dan dasar-dasar yang memungkinkan organisasi belajar (Cleveland dan Plastrik 1995). Pembelajaran organisasi juga dapat digambarkan sebagai seperangkat perilaku organisasi yang menunjukkan komitmen untuk belajar dan terus melakukan perbaikan. Pembelajaran organisasi merupakan jenis aktivitas dalam organisasi dimana sebuah organisasi belajar (Ortenblad 2001). Pembelajaran organisasi adalah organisasi yang dapat memotivasi orang-orang di dalamnya secara berkelanjutan, meningkatkan kapasitas mencapai apa yang dicita-citakan, mengembangkan pola pikir baru, mengutarakan aspirasi kolektif secara bebas dan para anggota organisasi belajar bersama berkelanjutan (Marlikan 2011).

\section{Kinerja (Job Performance)}

Kinerja (job performance) pegawai dapat diartikan sebagai sejauh mana seseorang melaksanakan tanggung jawab dan tugas kerjanya. Job performance adalah catatan hasil atau keluaran (outcomes) yang dihasilkan dari suatu fungsi pekerjaan atau kegiatan tertentu dalam periode waktu tertentu. Mondy menyatakan kriteria untuk mengukur kinerja adalah kuantitas kerja, kualitas kerja, inisiatif, kemampuan beradaptasi, dan kerjasama (Gomes dalam Murni, 2007).

Kinerja adalah suatu hasil kerja yang dicapai seseorang dalam melaksanakan tugas-tugas yang dibebankan kepadanya yang didasarkan atas kecakapan, pengalaman dan kesungguhan serta waktu (Hasibuan dalam Brahmasari dan Suprayetno 2008:128).

\section{Hubungan Servant Leadership Terhadap Pembelajaran Organisasi}

Setiap pengembangan praktek kepemimpinan hendaknya dibarengi dengan pengembangan spiritualitas pemimpin, karena hal ini akan meningkatkan perilaku positif anggota organisasi. Handoyo (2010) dalam penelitiannya yang berjudul: "Pengukuran Servant Leadership sebagai Alternatif Kepemimpinan di Institusi Pendidikan Tinggi pada Masa Perubahan Organisasi", menyimpulkan bahwa servant leadership dapat menjadi alternatif kepemimpinan di pendidikan tinggi dalam masa perubahan organisasi; semua dimensi dalam servant leadership yang terdiri dari organizational stewardship, wisdom, service, humality, vision, persuasive mapping, altruistic calling dan emotional healing adalah penting untuk diterapkan. Sementara Akhtar et al. (2012) dalam penelitiannya, menemukan bahwa servant leadership berdampak positif dan signifikan terhadap pembelajaran organisasi dan kinerja organisasi. Hasil penelitian lain (Hussain dan Wajib Al. 2012) menemukan bahwa semua dimensi servant leadership (love, empowerment, vision, humality, trust) berdampak positif signifikan terhadap kinerja karyawan. Berdasarkan hasil-hasil riset terdahulu, hipotesis dalam penelitian ini sebagai berikut:

H1: Servant leadership berpengaruh positif dan signifikan terhadap pembelajaran organisasi

H2: Servant leadership berpengaruh positif dan signifikan terhadap kinerja guru

\section{Hubungan Pembelajaran Organisasi Terhadap Kinerja Pegawai}

Pembelajaran organisasi adalah proses memperoleh pengetahuan secara individu dan kelompok yang berusaha mengaplikasikannya kedalam pekerjaan mereka dalam membuat keputusan saling mempengaruhi sebagai kapabilitas dinamik sebagai sumber keunggulan bersaing (Khandekar dan Sharma 2006). Kunartinah dan Sukoco (2010) membuktikan bahwa 
pembelajaran organisasi berpengaruh positif dan signifikan terhadap kinerja guru. Penelitian lain (Marlikan 2011) menemukan bahwa pembelajaran organisasi berpegaruh positif dan signifikan terhadap kinerja karyawan koperasi Syariah. Berdasarkan hasil-hasil riset terdahulu, hipotesis dalam penelitian ini sebagai berikut:

H3: Pembelajaran organisasi berpengaruh positif dan signifikan terhadap kinerja guru

\section{Hubungan Servant Leadership terhadap Kinerja Pegawai melalui Pembelajaran Organisasi sebagai Pemediasi}

Akhtar et al. (2012) membuktikan bahwa dampak servant leadership berpengaruh terhadap pembelajaran organisasi positif dan signifikan, dan selanjutnya berdampak positif pada kinerja organisasi. Kunartinah dan Sukoco (2010) dan Marlikan (2011) menemukan bahwa pembelajaran organisasi berpengaruh positif dan signifikan terhadap kinerja pegawai. Berdasarkan hasil-hasil riset terdahulu, hipotesis dalam penelitian ini sebagai berikut:

H4:Servant leadership berpengaruh terhadap kinerja guru dengan pembelajaran organisasi sebagai pemediasi.

Berikut ini model penelitian yang diajukan.

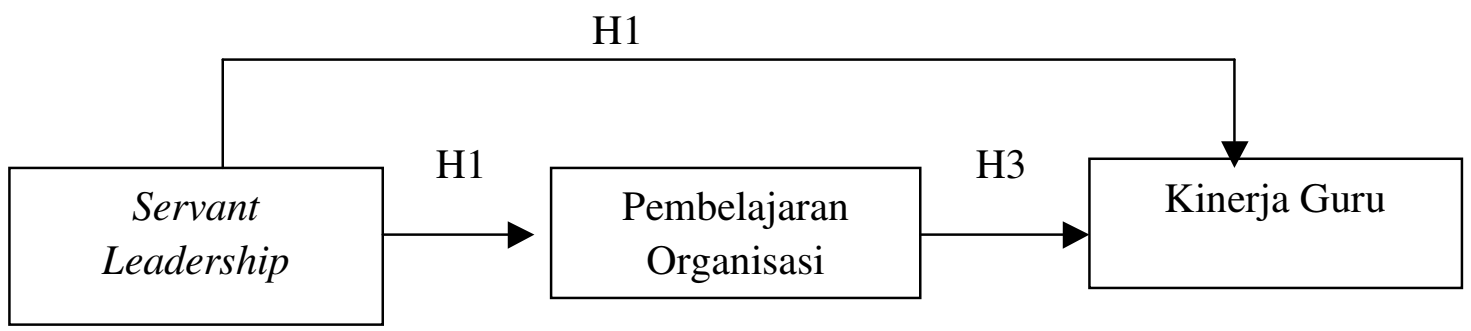

Gambar 1. Model Penelitian

\section{METODE PENELITIAN}

\section{Desain Penelitian}

Penelitian ini merupakan explanatory research yang akan membuktikan hubungan kausal antara variabel bebas (independent variable), variabel antara (intervening variable), dan variabel terikat (dependent variable). Desain penelitian ini adalah penelitian kausal (Sekaran, 2007), dimana dalam penelitian ini bertujuan menguji pengaruh servant leadership terhadap pembelajaran organisasi serta menguji pengaruh langsung dan tidak langsung servant leadership terhadap kinerja guru dengan pembelajaran organisasi sebagai pemediasi. Metode penelitian yang digunakan adalah metode survei pada guru-guru SMA dan SMK Negeri dan Swasta se-kota Madiun.

\section{Populasi dan Sampel}

Populasi penelitian ini adalah guru-guru yang telah bekerja selama $\geq 5$ tahun dan sudah berstatus pegawai negeri sipil (PNS) SMA dan SMK Negeri serta guru tetap SMA dan SMK Swasta se-kota Madiun. Penelitian ini melibatkan 33 obyek yaitu SMA dan SMK Negeri dan Swasta sekota Madiun. Karena jumlah populasi lebih dari 100, maka penelitian yang 
digunakan adalah penelitian sampel, dengan jumlah sampel ditentukan sebesar $20 \%$ dari jumlah guru setiap sekolah (mengacu Arikunto, 1997). Jumlah sampel guru sebanyak 281 guru. Pengambilan sampel menggunakan metode proportional sampling.

\section{Definisi Operasional Variabel}

\section{a. Servant Leadership}

Servant leadership atau kepemimpinan pelayan adalah suatu kepemimpinan yang berawal dari perasaan tulus yang timbul dari dalam hati yang berkehendak untuk melayani, yaitu untuk menjadi pihak pertama yang melayani (Greenleaf, 1970). Kepemimpinan servant diukur menggunakan 10 indikator dari Spears (2005) yaitu: listening, empathy, foresight, awareness, persuasion, conceptualization, healing, stewardship, commitment to the growth of people, dan community building.

\section{b. Pembelajaran Organisasi}

Organisasi pembelajar haruslah terus menerus mengembangkan kapasitasnya dalam menciptakan hasil yang ingin dicapai (Senge, 1990). Pengukuran pembelajaran organisasi menggunakan dimensi: keahlian pribadi, berbagi visi, model mental, berpikir sistem, pembelajaran kelompok (Marquardt 1996; Senge 1990).

\section{c. Kinerja Guru}

Menurut Hersey dan Blanchard (2001), kinerja merupakan suatu fungsi dari motivasi dan kemampuan. Untuk menyelesaikan tugas atau pekerjaan, seseorang harus memiliki derajat kesediaan dan tingkat kemampuan tertentu. Kinerja adalah "succesfull role achievement" yang diperoleh seseorang dari perbuatan perbuatannya (As'ad 1991: 46 47) Pengukuran kinerja guru menggunakan dimensi: kompetensi pedagogik, kompetensi kepribadian, kompetensi sosial, kompetensi profesional (UU No. 16 th 2007).

\section{Teknik Analisis Data}

a. Uji Kualitas Data

Uji kualitas data terdiri dari dua uji, yaitu uji validitas dan uji reliabilitas.

b. Analisis Regresi Linier Sederhana dan Berganda

Analisis regresi linier sederhana dan berganda digunakan untuk mengetahui arah dan besarnya pengaruh langsung dan tidak langsung variabel bebas $(\mathrm{X})$ terhadap variabel terikat (Y). Persamaan linier regresi yang diuji adalah:

$$
\begin{aligned}
& \mathrm{PO}=\beta_{0+} \beta_{1} \mathrm{SL}+\mathrm{e} \\
& \mathrm{KG}=\beta_{0+} \beta_{2} \mathrm{PO}+\mathrm{e} \quad \mathrm{KG}=\beta_{0+} \beta_{1} \mathrm{KS}+\beta_{2} \mathrm{PO}+\mathrm{e}
\end{aligned}
$$

Keterangan:

$$
\begin{array}{lll}
\text { PO : Pembelajaran Organisasi } & \text { KG } & : \text { Kinerja Guru } \\
\beta_{0}: \text { konstanta } & \beta_{\mathrm{i}} & : \text { koefisien regresi ke i }
\end{array}
$$




\section{c. Uji Hipotesis}

\section{KS : Servant Leadership}

Uji hipotesis yang diguanakan uji-t dan analisis jalur (Path Analysis). Alat uji yang digunakan adalah koefisien korelasi parsial (r) atau koefisien regresi linier berganda ( $\beta$ ). Koefisien regresi linier berganda merupakan alat uji untuk mengetahui dan mengukur variabel-variabel yang mempunyai keeratan pengaruh terhadap variabel terikat (Y) secara parsial. Pengujian ini menggunakan uji t dengan melihat apakah nilai-nilai koefisien yang diperoleh berbeda secara signifikan atau tidak antara $\mathrm{t}$ hitung dan $\mathrm{t}$ tabel pada tingkat keyakinan 5\% $(\alpha=0,05)$. Untuk uji mediasi, ada tiga kemungkinan uji mediasi, yaitu (1) mediasi terbukti secara penuh (fully mediating), (2) mediasi terbukti secara parsial (partially mediating) dan (3) mediasi tidak terbukti. Baron dan Kenny (1986) menyatakan empat kondisi yang harus terpenuhi untuk menguji efek mediasi yaitu: 1) Variabel independen berpengaruh signifikan terhadap variabel mediasi; 2) Variabel independen berpengaruh signifikan terhadap variabel dependen; 3) Variabel mediasi berpengaruh signifikan terhadap variabel dependen ketika variabel independen dimasukkan dalam persamaan regresi; 4) Jika pengaruh signifikan variabel independen terhadap variabel dependen menjadi tidak signifikan ketika dimasukkan variabel mediasi, maka terjadi mediasi secara penuh (fully mediating), jika tetap signifikan tetapi kekuatannya berkurang, maka terjadi partially mediating.

\section{HASIL DAN PEMBAHASAN}

Berikut adalah rangkuman hasil analisis regresi linier sederhana dan regresi linier berganda serta path analysis.

1. Pengaruh Langsung (Direct Effect) Servant Leadership terhadap Pembelajaran Organisasi dan Kinerja Guru

Tabel 1.

Ringkasan Hasil Analisis Direct Effect

\begin{tabular}{|c|c|c|c|c|c|c|}
\hline & Estimate & S.E. & $\begin{array}{c}\text { Standardiz } \\
\text { ed } \\
\text { Coefficient } \\
\text { s Beta }\end{array}$ & $\begin{array}{c}\text { C.R. } \\
\text { (t-hit) }\end{array}$ & P & Keterangan \\
\hline PO <--- SL & 0.327 & 0.034 & 0.543 & 9.563 & 0.000 & Signifikan \\
\hline KG <--- PO & 0.940 & 0.065 & 0.697 & 14.386 & 0.000 & Signifikan \\
\hline KG <--- SL & 0.364 & 0.049 & 0.448 & 7.410 & 0.000 & Signifikan \\
\hline
\end{tabular}

Sumber: Output SPSS

2. Pengaruh Tidak Langsung (Indirect Effect) Servant Leadership terhadap Kinerja Guru dengam Pembelajaran Organisasi sebagai Variabel Pemediasi

Tabel 2

Ringkasan Hasil Analisis Indirect Effect dengan PO sebagai Variabel Kontrol

\begin{tabular}{|l|l|l|c|c|c|c|}
\hline & Estimate & S.E. & $\begin{array}{c}\text { Standardize } \\
\text { Coefficients } \\
\text { Beta }\end{array}$ & $\begin{array}{c}\text { C.R. } \\
\text { (t-hit) }\end{array}$ & P & Keterangan \\
\hline
\end{tabular}




\begin{tabular}{|c|r|r|r|r|r|c|}
\hline KG <--- KS & 0.080 & 0.047 & 0.098 & 1.713 & $\begin{array}{r}0.08 \\
8\end{array}$ & Tidak Signifikan \\
\hline KG <--- PO & 0.868 & 0.077 & 0.644 & 11.206 & $\begin{array}{r}0.00 \\
0\end{array}$ & Signifikan \\
\hline
\end{tabular}

Sumber: Output SPSS

Berdasarkan ringkasan tabel 1 dan tabel tabel 2, dapat disimpulkan bahwa ke 4 hipotesis yang diajukan diterima yaitu: 1) servant leadership berpengaruh positif dan signifikan terhadap pembelajaran organisasi; 2) servant leadership berpengaruh positif dan signifikan terhadap kinerja guru; 3) pembelajaran organisasi berpengaruh positif dan signifikan terhadap kinerja guru); dan 4) servant leadership berpengaruh terhadap kinerja guru dengan pembelajaran organisasi sebagai pemediasi.

Untuk menganalisis pengaruh pembelajaran organisasi sebagai pemediasi hubungan servant leadership dengan kinerja guru, berpedoman pada Baron dan Kenny (1986). Dari tabel 1 dan tabel 2 empat kondisi untuk menguji efek mediasi terpenuhi, yaitu: 1) Variabel independen (servant leadership) berpengaruh signifikan terhadap variabel mediasi (pembelajaran organisasi); 2)Variabel independen (servant leadership) berpengaruh signifikan terhadap variabel dependen (kinerja guru); 3)Variabel mediasi (pembelajaran organisasi) berpengaruh signifikan terhadap variabel dependen ketika variabel independen (kinerja guru) dimasukkan dalam persamaan regresi; 4) Pembelajaran organisasi memediasi secara penuh (fully mediating), karena pengaruh servant leadership terhadap kinerja guru menjadi tidak signifikan ketika dimasukkan variabel mediasi (pembelajaran organisasi).

\section{a. Dampak Servant Leadership terhadap Pembelajaran Organisasi dan Kinerja Guru}

Servant leadership yang diukur dengan 10 indikator dari Spears (2005) yaitu: listening, empathy, foresight, awareness, persuasion, conceptualization, healing, stewardship, commitment to the growth of people, dan community building adalah contoh perilaku kepemimpinan yang diperlukan dalam pengembangan pembelajaran organisasi. Servant leadership adalah kepemimpinan yang mendorong seseorang untuk melayani orang lain yaitu berfokus pada kepentingan karyawan atau sumber daya manusia, dan tetap fokus pada upaya untuk mencapai apa yang menjadi tujuan utama (visi dan misi) dari organisasi; sedangkan kepemimpinan transformasional berfokus pada pencapaian visi organisasi dan tujuan organisasi dengan membangun komitmen bawahan ke arah hasil organisasi.

Temuan penelitian ini membuktikan bahwa servant leadership berpengaruh positif dan signifikan terhadap pembelajaran organisasi dari para guru. Hasil penelitian ini selain mendukung penelitian-penelitian terdahulu, juga memberikan wacana baru bagi pengembangan praktek kepemimpinan di lembaga pendidikan, selain tingkat perguruan tinggi, dimana dalam lembaga pendidikan di tingkat SMA dan SMK, servant leadership berdampak positif terhadap kinerja para guru dengan pembelajaran organisasi sebagai pemediasi. Dalam penelitian ini, kepemimpinan servant diukur dengan 10 indikator servant leadership dari Spears, sedangkan kinerja guru diukur dengan berdasarkan dimensi: kompetensi pedagogik, kompetensi kepribadian, kompetensi sosial, kompetensi profesional (UU No. 16 th 2007). 
b. Dampak Servant Leadership terhadap Kinerja Guru melalui Pembelajaran Organisasi sebagai Pemediasi

Setiap pengembangan praktek kepemimpinan hendaknya dibarengi dengan pengembangan spiritualitas pemimpin, karena hal ini akan meningkatkan perilaku kepemimpinan servant, yang pada gilirannya akan berdampak pada peningkatan kinerja. Handoyo (2010) dalam penelitiannya yang berjudul: "Pengukuran Servant Leadership sebagai Alternatif Kepemimpinan di Institusi Pendidikan Tinggi pada Masa Perubahan Organisasi", menyimpulkan bahwa servant leadership dapat menjadi alternatif kepemimpinan di pendidikan tinggi dalam masa perubahan organisasi; semua dimensi dalam servant leadership yang terdiri dari organizational stewardship, wisdom, service, humality, vision, persuasive mapping, altruistic calling dan emotional healing adalah penting untuk diterapkan. Sementara Akhtar et al., (2012) dalam penelitiannya, menemukan bahwa servant leadership berdampak positif terhadap kinerja organisasi melalui pembelajaran organisasi sebagai pemediasi. Hasil penelitian lain (Hussain dan Wajib Al., 2012) menemukan bahwa semua dimensi servant leadership (love, empowerment, vision, humality, trust) berdampak positif signifikan terhadap kinerja karyawan.

Pemimpin servant dengan 10 karakteristik yang dikembangkan Spears (listening, empathy, foresight, awareness, persuasion, conceptualization, healing, stewardship, commitment to the growth of people, dan community building) terbukti dampaknya terhadap pembelajaran organisasi dan pada akhirnya berdampak positif terhadap kinerja para guru itu sendiri. Hal ini dapat dijelaskan sebagai berikut: karakteristik servant leadership adalah kepemimpinan yang mendorong seseorang untuk melayani orang lain yaitu berfokus pada kepentingan karyawan atau sumber daya manusia, dan tetap fokus pada upaya untuk mencapai apa yang menjadi tujuan utama (visi dan misi) dari organisasi, sehingga servant leadership berdampak signifikan terhadap pembelajaran organisasi dan kinerja pegawai. Jika dikaitkan dengan teori perilaku kepemimpinan yang efektif baik dari hasil studi Ohio State University dan Michigan University, bahwa kepemimpinan yang efektif adalah pemimpin mampu menunjukkan perilaku yang berorientasi tugas, berorientasi hubungan dan perubahan adalah tinggi, atau dikenal dengan istilah high-high leader (Yukl, 2005). Karakteristik high-high leader terdapat pada servant leadership.

\section{SIMPULAN}

Berdasarkan hasil pengujian hipotesis, disimpulkan bahwa:1)kepemimpinan servant berpengaruh positif dan signifikan terhadap pembelajaran organisasi;2) kepemimpinan servant berpengaruh positif dan signifikan terhadap kinerja guru;3) pembelajaran organisasi berpengaruh positif dan signifikan terhadap kinerja guru; 4)pembelajaran organisasi memediasi secara penuh hubungan servant leadership dengan kinerja guru.

Temuan penelitian ini diharapkan dapat menjadi acuan bagi penelitian lain yang mengkaji praktek kepemimpinan di Indonesia khususnya, karena kajian khususnya servant leadership masih sedikit. Oleh karena itu untuk pengembangan riset serupa, dapat ditambahkan beberapa variabel penelitian yang dipengaruhi praktek servant leadership, seperti: komitmen organisasional (Cerit, 2010); kepuasan kerja (West et al., 2008); dan OCB (Srimulyani, 2012; Bambale et al., 2012). 


\section{DAFTAR REFERENSI}

Akhtar S, Azeem, et al 2012, 'Impact of Transformational and Servant Leadership on Organizational Performance: A Comparative Analysis', Actual Problems Economics 2/4: 309-315.

Aorora, Dewi. 2009. 'Model Kepemimpinan Servant Leadership pada Institut Pertanian Bogor', Skripsi pada Departemen Manajemen, Fakultas Ekonomi dan Manajemen, Institut Pertanian Bogor, Bogor.

Arikunto, Suharsimi. 2003, Manajemen Penelitian, Rineka Cipta, Jakarta

As’ad,Moh.1991. Psikologi Industri.Edisi 4. Yogyakarta:Liberty

Baron, R. M., Kenny, D. A. 1986. The Moderator-mediator variable distinction in social psychological research: conceptual, strategic, and statistical considerations. Journal of Personality and Social Psychology, 51/6: 1173-1182.

Bambale, Abdu Ja'afaru, Faridahwati MS., Chandrakantan. 2012. Servant Leadership as Employee-Organization Approach for Performance of Employee Citizenship Behaviors in the Nigeria's Electric Power Sector. Journal of Marketing and Management, 3/1 : 1-21.

Brahmasari, I. dan Suprayetno, A. 2008. Pengaruh Motivasi Kerja, Kepemimpinan, dan Budaya Organisasi Terhadap Kepuasan Kerja Karyawan Serta Dampaknya Pada Kinerja Perusahaan. Jurnal Manajemen dan Kewirausahaan 10/ 2: 124-135.

Cerit, Yusuf. 2010. The Effects of Servant Leadership on Teachers' Organizational Commitment in Primary Schools in Turkey. Int. J. Leadership in Education, July-September, Vol. 13 (3), hal: 301-317.

Cleveland, J., and P., Plastrik, 1995. Learning Organization and TQM. In A.M. Hoffman and D.J. Julius (Eds), Total Quality Management: Implications for Higher Education, Maryville, MO: 233- 243.

Garvin, David, 2000. Learning in Action: A Guide to Putting the Learning Organization to Work. Boston: Harvard Business School Press.

Glatthorn, A. A. 2000. The Principal as Curriculum Leader: Shaping What is Taught and Tested. Thousand Oaks, California: Corwin Press, Inc

Green, R.L. 2001. Practicing the Art of Leadership: A Problem-based Approach to Implementing The ISLLC Standards. Columbus, Ohio: Merrill Prentice Hall.

Greenleaf, R.K. 1970. The Servant as Leader. Indianapolis: The Robert K. Greenleaf Center: $1-37$.

Handoyo, Seger. 2010. Pengukuran Servant Leadership sebagai Alternatif Kepemimpinan di Institusi Pendidikan Tinggi pada Masa Perubahan. Makara of Social Sciences and Humanities Series 14/2: 130-140. 
Hersey,Paul dan Blanchard, Kenneth H. 2001. Management of Organization Behavior. Prentice-Hall, New Jersey.

Hugo Zagorsek, Vlado Dimovski, Miha Skerlavaj. 2009. Transactional and Transformational Leadership Impacts on Organizational Learning. JEEMS 2.

Hussain,Tajammal dan Wajib Al. 2012. Effects Of Servant Leadership on Followers' Job Performance. Sci., Tech. And Dev 31/4: 359-368. http://www.pcst.org.pk/journal/JN/2012/

Khandekar, A., and A., Sharma. 2006. Organizational Learning and Performmance: Understanding Indian Scenario in Present Global Context, Education \& Training 48/(8/9): 682-293.

Kunartinah dan Fajar Sukoco. 2010. Pengaruh Pendidikan dan Pelatihan, Pembelajaran Organisasi terhadap Kinerja dengan Kompetensi sebagai Mediasi. Jurnal Bisnis dan Ekonomi (JBE) 17/1: $74-84$

Marquardt, M.J. 1996. Building the Learning Organization. New York: McGraw-Hill Comapanies, Inc.

Marlikan, Muchni. 2011. Pengaruh Pembelajaran Organisasi dan Motivasi Kerja terhadap Kinerja Karyawan Koperasi Syariah.Jurnal Manajemen Bisnis 1/1.

Murni N. I. H. L. 2007. Hubungan antara Gaya Kepemimpinan dan Kompensasi terhaap Kinerja Karyawan PT. Imawi Benjaya (Tupperware Indonesia) di Jakarta. Jurnal Manajemen Publik dan Bisnis.

Northouse.G Peter. 2001. Leadership: Theory and Practice. London :Sage Publiscations.

Ortenblad, A. 2001. On Differences between Organizational Learning and Learning Organization, The Learning Organization, Vol.8, No.3.

Sekaran, Uma. 2007. Research Methods for Business. Buku 1. Jakarta: Penerbit Salemba Empat.

Senge, P.M. 1990. The Leader's New York: Building Learning Organizations, Sloan Management Review: 32.

Spears, Larry C. 2005. The Understanding and Practice of Servant Leadership. Servant Leadership Research Roundtable. Published by the School of Global Leadership \& Entrepreneurship, Regent University.

Srimulyani, Veronika Agustini. 2012. Anteseden Organizational Citizenship Behavior: Studi Pada Guru-guru SMA di Kota Madiun. Jurnal Widya Warta 1/ Tahun XXXVI. 
Srimulyani, Veronika Agustini. 2011, What is Servant Leadership?, diunduh 22 September 2012 http://portal.widyamandala.ac.id/jurnal/index.php/krida/article/view/23/pdf

UU No. 16 th 2007.

Weller, L. D, Jr and Weller, S. (2000). Quality Human Resources Leadership: A Principal's Handbook. Maryland: The Scarecrow Press, Inc

West, G.R. Bud, dan Mihai Bocarnea. 2008. Servant Leadership and Organizational Outcomes: Relationships in United States and Filipino Higher Educational Settings.Published by the School of Global Leadership \& Entrepreneurship, Regent University.

Yukl, Gary. 2005. Leadership in Organization. Prentice Hall, Inc. 